\title{
6 \\ Dawn of the Yan'an Era
}

Early in January 1937, Mao Zedong and the CCP Center moved into Yan'an. Over the next decade, this small Shaanbei town became the symbol of an alternative Chinese future. Here Mao Zedong rose to dominate the party, wrote the essayssome vivid and stirring, some turgid and pedantic-that came to define Mao Zedong Thought, and here the party developed the practices of self-reliance, political rectification, and "mass line" that would set the future course of the Communist revolution. Tens of thousands of young people flocked to Yanan to join the revolution, transforming the region and ultimately the nation. Their patriotic commitment to build a new China while living simply in harsh conditions would be celebrated as the "Yan'an spirit," and today Chinese and foreign tourists visit the city to explore the homes of the leaders and absorb the celebration of Yan'an's glory years in the town's massive Revolutionary Museum. But the Yan'an of today is far from the dusty frontier town with a mere three thousand residents that Mao entered in 1937. Described by one visitor as "the quaintest and most picturesque little fortress city imaginable," it was also a dirty town of flies and manure-littered streets that became impassable quagmires when it rained. There were no multistory buildings, only caves carved into the hillsides; no motorcars plied the unpaved streets; and a single rickety bridge crossed the Yan River that flowed through the center of town. ${ }^{1}$ When the Red Army entered, the local merchants greeted them with rations for the troops, just as they would have welcomed any warlord army that threatened public order. Most of the landlords fled, leaving their compounds to be occupied by the Communist leaders. ${ }^{2}$

If Yanan was small, so was the Communist border region that surrounded it. When the Xian Incident broke out, the Red Army controlled only Bao'an, which Edgar Snow had visited in 1936, and neighboring Ansai-both poor and sparsely populated counties-plus Yanchi in Ningxia, stretches along the Great Wall north of Bao'an, and the Shaanxi-Gansu border. In addition, several counties in eastern Gansu had been occupied by He Long's army at the end of its Long March. After 
the Northeast Army withdrew during the Xian Incident, the Communists occupied Yan'an and neighboring Ganquan and Yanchang Counties. ${ }^{3}$ This was a far smaller territory than the eventual Shaan-Gan-Ning Border Region, and as before the Xian Incident, Mao and the Communist leadership had no desire to stay in this poor, barren, and sparsely populated corner of China. Only a protracted series of complex negotiations and external events left Mao and the Communist Party reluctant occupants of the Yan'an caves.

\section{RENEGOTIATING THE XI'AN TRUCE}

As the party Center entered Yan'an, the shifting military situation in Shaanxi became a focus of ongoing negotiations with Chiang Kai-shek and the Nanjing government. During the Xian Incident, the armies of Zhang Xueliang and Yang Hucheng had withdrawn from the desolate north to protect Xi'an, and they invited the Red Army to move south as well. Xu Haidong's Fifteenth Army was dispatched across the Wei River and advanced all the way to southern Shaanxi, working to revive scattered guerrilla units in the area through which his army had passed in 1934-35. ${ }^{4}$ Mao hoped to move the main force of the Red Army to this same region, which was far richer than the north and offered multiple options for expansion. ${ }^{5}$ This, however, would have brought the Communist forces into the upper reaches of the Han River, an increasingly prosperous area whose navigable waters flowed into the Yangzi metropolis of Wuhan. This was the same area from which commoner rebels had risen to found the Han dynasty of ancient China, and from which Li Zicheng had launched his final assault to topple the Ming, precedents of which Chiang Kai-shek was surely aware, and he strongly opposed this option. ${ }^{6}$ At least one of Chiang's counter-proposals was equally unrealistic. He offered the Communists a base in the barren wastes of western Gansu, precisely the area where Muslim armies were decimating the remains of Zhang Guotao's forces, the West Route Army. The Communists were predictably unwilling to accept a desolate base far from the Japanese front. ${ }^{7}$ Some Communist commanders revived the plan to advance through Ningxia toward the Soviet border, taking advantage of the winter months to cross the frozen Yellow River. All these options to escape Yan'an were under active consideration until Chiang Kai-shek offered financial support for a reorganized Red Army, at which point the Communists withdrew the Fifteenth Army from southern Shaanxi and abandoned plans for offensive operations in the south. ${ }^{8}$ Resigned to making Shaanbei their base, they managed to maintain units on the northern fringes of the Wei River valley, more productive lands to help feed their armies. One clear advantage of Shaanbei was that it represented a plausible refuge for remnants of the battered West Route Army. When this elite portion of Zhang Guotao's Fourth Army had crossed the Yellow River in Gansu and headed west toward Xinjiang, it represented almost half of the entire Red Army. In early 1937, the party was anxious to recover what it could of its key units and officers. ${ }^{9}$ 
In the months leading up to the Xian Incident, the Communists had carefully cultivated relations with Zhang Xueliang's Northeast Army and Yang Hucheng's Northwest Army in hopes of establishing a secure anti-Japanese alliance in Northwest China. An alliance of these three armies remained the party's objective throughout the negotiations in Xian. ${ }^{10}$ These hopes were dashed when, following Chiang Kai-shek's release, the Nanjing government put Zhang Xueliang on trial and convicted him of gross insubordination. Zhang's Northeast Army was sent out of the region to bases in Henan and Anhui. ${ }^{11}$ At the same time, Chiang told Yang Hucheng that he would not tolerate an independent army in the Northwest. Chiang's lieutenants assured him that Yang was "rude and stupid," a "feudal" warlord and locally despised. By April, Yang had been removed and sent abroad, his local regime dismantled. Chiang Kai-shek sent a loyal general to take command in Xian, and once again the Communists were alone in the Northwest, forced to fend for themselves. ${ }^{12}$ Militarily, their situation was more precarious than before Xi'an.

Politically, the situation did not look much better. In December 1936, to resolve the Xi'an Incident, T. V. Soong had flown to the city with Song Meiling, his sister and Chiang's wife. T. V. served as the principal negotiator, shuttling back and forth between Chiang Kai-shek and Zhou Enlai. To the Communists, he represented the liberal Anglo-American faction of the Guomindang, in which they placed the greatest hope for a united front against Japan. Though Chiang Kai-shek resolutely refused to sign any agreement under duress, Soong assured the Communists that the Generalissimo had agreed to cease attacks on the Red Army and reorganize the Nanjing government to exclude pro-Japanese elements. Though Soong abjured any ambitions of his own, he obviously hoped that his efforts to save the Generalissimo's life would win him a key role in the new government.

Whatever concessions Soong had extracted from Chiang unraveled as soon as the Generalissimo returned to a joyous welcome in Nanjing. According to Soong, Chiang had assured Zhang Xueliang and Yang Hucheng that "he would pardon them for their act." Soong also reported that Chiang had agreed to keep Zhang Xueliang in the Northwest and not send in central government troops. None of these agreements were carried out. ${ }^{13}$ Soong had evidently promised more than he could deliver. For his part, Chiang Kai-shek displayed no gratitude for the role Soong had played in his release. The Generalissimo's relations with his brother-in-law would always be troubled. While Chiang relied on the suave Harvard-educated, English-speaking banker when he needed him, he remained suspicious of Soong's ill-disguised ambition. ${ }^{14}$ He offered Soong no position in a reformed government, keeping him out of power until 1940, when Soong's suave manner and business connections were required to secure aid from China's allies. With T. V. Soong's mediation in Xian, the Communists had hoped and expected that the incident would enhance the power of anti-Japanese elements in Nanjing, but in fact it was pro-Japanese forces that seemed to gain strength. Wang Jingwei, soon to become wartime leader of the Japanese puppet government in Nanjing, returned from 
forced exile in January, and He Yingqin, the military leader of the "pro-Japanese" clique whom Mao described as China's Franco, remained in power and would soon become chief of the general staff in Chiang's wartime armies. ${ }^{15}$ In the Yangzi valley, Chiang intensified military actions to eliminate the last pockets of Communist resistance, the guerrillas left behind by the Long March, soon to be reorganized as the New Fourth Army. ${ }^{16}$ In early March, Chiang Kai-shek met with the Japanese ambassador and assured him that "my government's policy toward the Communist Party has not changed." 17

With the collapse of the Xian understandings and the expulsion of the CCP's military allies in the Northwest, things looked bleak for the Communists in the early months of 1937. The Xian Incident did not look like a turning point in Chinese history. Beneath the surface, however, a subtle thaw was melting the sharp confrontation between the Communist and Nationalist parties. In its February 1937 plenum, the Guomindang adopted a policy to "root out the Red menace" (genjue chihuo 根绝赤祸). This hardly seemed promising, but the Communists took hope from Chiang Kai-shek's speech emphasizing political rather than military solutions. ${ }^{18}$ In March, the Soviet Union encouraged this thaw by promising to return the Generalissimo's son, Chiang Ching-kuo (Jiang Jingguo), who had been studying and working in Russia since the 1920s. He would arrive back in China in April. ${ }^{19}$ Most significantly, military operations against the Communist base stopped, as negotiations continued in Xi'an to resolve the crisis, and Chiang agreed to financial support of a reorganized Red Army. ${ }^{20}$

The initial negotiations focused not on the later Shaan-Gan-Ning Border Region, which was never a major concern of the Communist leadership, but on the size and control of the Red Army. Chiang Kai-shek thought that quantitative concessions on the army's size would satisfy his adversaries. During the pre-Xian negotiations, Chiang's representative, Chen Lifu, had offered to absorb and support a Red Army of 3,000 soldiers. In February 1937, Chiang indicated that he had already agreed to support 5,000 men, and now increased his offer to two divisions with 15,000 men. In March, the number had increased to 27,000, and in July to 45,00o. ${ }^{21}$ Similarly, when it came to the future border region in Shaanbei, Chiang told Zhou Enlai that he wished to debate, not the number of counties to be included, but the nature of the local regime. ${ }^{22}$ For Chiang, the issue was never the size of the Red Army or the territory it administered but the degree to which it would be subject to his authority.

In many respects, Chiang's position remained unchanged by the Xi'an episode. He was confident that the small Red Army represented a lesser threat to his power than the brief revolt of the Southwest warlords in the spring of 1936 . He denied that he had ever promised to reorganize the Nanjing government as T. V. Soong had alleged in Xian. He continued to use the divisive slogan of "internal pacification and external resistance." ${ }^{23}$ Most importantly, he insisted that his policy was not to tolerate the Communist armies (ronggong 容共) but to absorb and reorganize 
them (biangong 编共). Officers would be centrally appointed, and the Red Army had to obey the orders of the National Government. ${ }^{24}$ The Red Army would be treated like the many warlord armies that Chiang had absorbed since the Northern Expedition of 1927. As for the united front, Chiang's model was the Sun-Joffe agreement of 1922, which had led to the first GMD-CCP alliance: Communists had been admitted as members of the Nationalist Party and the Communist International had agreed that China was not ready for communism. ${ }^{25}$ But this was a model that the CCP had long denounced as "right opportunism," and there was little hope that it was willing to turn back the clock on this score. Finally, on the Communist demand for the release of political prisoners, Chiang agreed that if his critics would repent their errors (which amounted to renouncing Communism), he would release them. ${ }^{26}$

As Chiang Kai-shek deployed his own forces to surround the Red Army in Shaanxi, it became clear to the CCP that leaving Shaanbei for a more hospitable locale would no longer be possible. At this point, the status of the Shaanbei regime became a focal point of negotiation. Here again, Chiang's position was clear: the Communist-controlled soviet must be reorganized as a special administrative district following national laws with nationally appointed officials. On this, his stance was unwavering, and the National Government never formally recognized a border region (bianqu 边区) with a separate administration. ${ }^{27}$ In Chiang's words, "In order to maintain military and political unity, we cannot permit others to delimit regions that will be separate and independent." ${ }^{28}$ At the heart of his position was the conviction that a modern state could not have two separate administrations. He consistently characterized the alternative as "feudal" and linked it to a new form of warlordism. ${ }^{29}$

On paper, the Communist position was not that different. In a formal proposal to the National Government the party called for an end to civil war, protection of the freedom of political expression, the summoning of all parties for national salvation, preparation for war against Japan, and improvement of the people's livelihood. If the Guomindang would adopt these policies the Communists offered four significant concessions: (1) cessation of all military efforts to overthrow the National Government; (2) "transformation of the soviet government into a special administrative district [tequ zhengfu 特区政府] of the National Government, and the Red Army into a unit of the National Revolutionary Army, under the direction of the Nanjing central government and its military committee"; (3) establishment of a democratic regime by popular election in the special district; and (4) an end to the confiscation of landlord lands. ${ }^{30} \mathrm{On}$ its face, the second principle seemed to correspond to the Guomindang position.

Clearly, the devil was in the details. From the Wayaobu meeting of December 1935, when the party Center learned of the Communist International's new united front policy, a critical component of Communist policy was the independence of the party and its army. Mao and the party's new leaders stressed the clear distinction 
between this period and the united front of the 1920s: the party now had its own army and its own revolutionary base. It was not prepared to give these up. In this, it had the full support of the Communist International. ${ }^{31}$ In explaining its new policy, the party stressed that it would continue to guarantee the rights of workers and peasants in the former soviet and "the political and organizational leadership of the party" in the army. ${ }^{32}$ It also, in a separate document, assured local activists that the gains of the soviet period would not be reversed. ${ }^{33}$ The party seems to have assumed that just as Chiang had absorbed other local armies in his National Revolutionary Army without changing their command structure, so would he include the Red Army with its own commanders and political officers. This, however, was not Chiang's intent, and on the eve of full-scale war with Japan, his position was unwavering.

In June 1937, Zhou Enlai flew to Chiang's summer retreat in Lushan for one more round of negotiations. Now Chiang proposed a new joint organization, to be called the National Revolutionary Alliance (Guomin Geming Tongmenghui 国民革命同盟会), reviving the name of the party that Sun Yat-sen had led in the 1911 Revolution. Both parties were to be equally represented in this body, but Chiang insisted on the deciding voice in the likely event of disagreement. He raised the possibility that this Alliance might evolve into a single party in the future, which, once again, recalled the model of the 1920s. Chiang now agreed to a reorganized Red Army of forty-five thousand men, with officers appointed by the central government. Then came the poison pill: not only were Mao Zedong, Zhu De, and the other Red Army commanders excluded from positions in the reorganized Red Army, they were to leave the army for other work. ${ }^{34}$ Predictably, Zhou Enlai declared this totally unacceptable, and when Mao Zedong met a group of foreign journalists, he spoke of the "uncertain future" of the united front. ${ }^{35}$ Such was the fragile state of Communist-Guomindang relations when war broke out in July 1937.

\section{SHAAN-GAN-NING ON THE EVE OF WAR}

While these tortuous negotiations continued between the leaders of the rival parties, a seemingly tranquil dual regime was being established in Shaanbei. When the American journalist T. A. Bisson visited in June, he reported that "something approaching a political lull existed in Yenan [Yan'an] and elsewhere in China." ${ }^{36}$ Most Shaanbei counties still had Guomindang magistrates, and the old local tax and security apparatus (baojia) remained intact. ${ }^{37}$ In Yan'an and three neighboring counties to the south and east, there were dual administrations with Guomindang magistrates in the county towns. ${ }^{38}$ The remnants of the old administration persisted throughout most of the border region. The Guomindang hoped to gain favor by distributing relief grain, and its representative claimed to have done this in all Shaanbei counties except Bao'an, which alone was totally under Communist control. ${ }^{39}$ The rival armies had friendly interactions. In May, the Nanjing government 


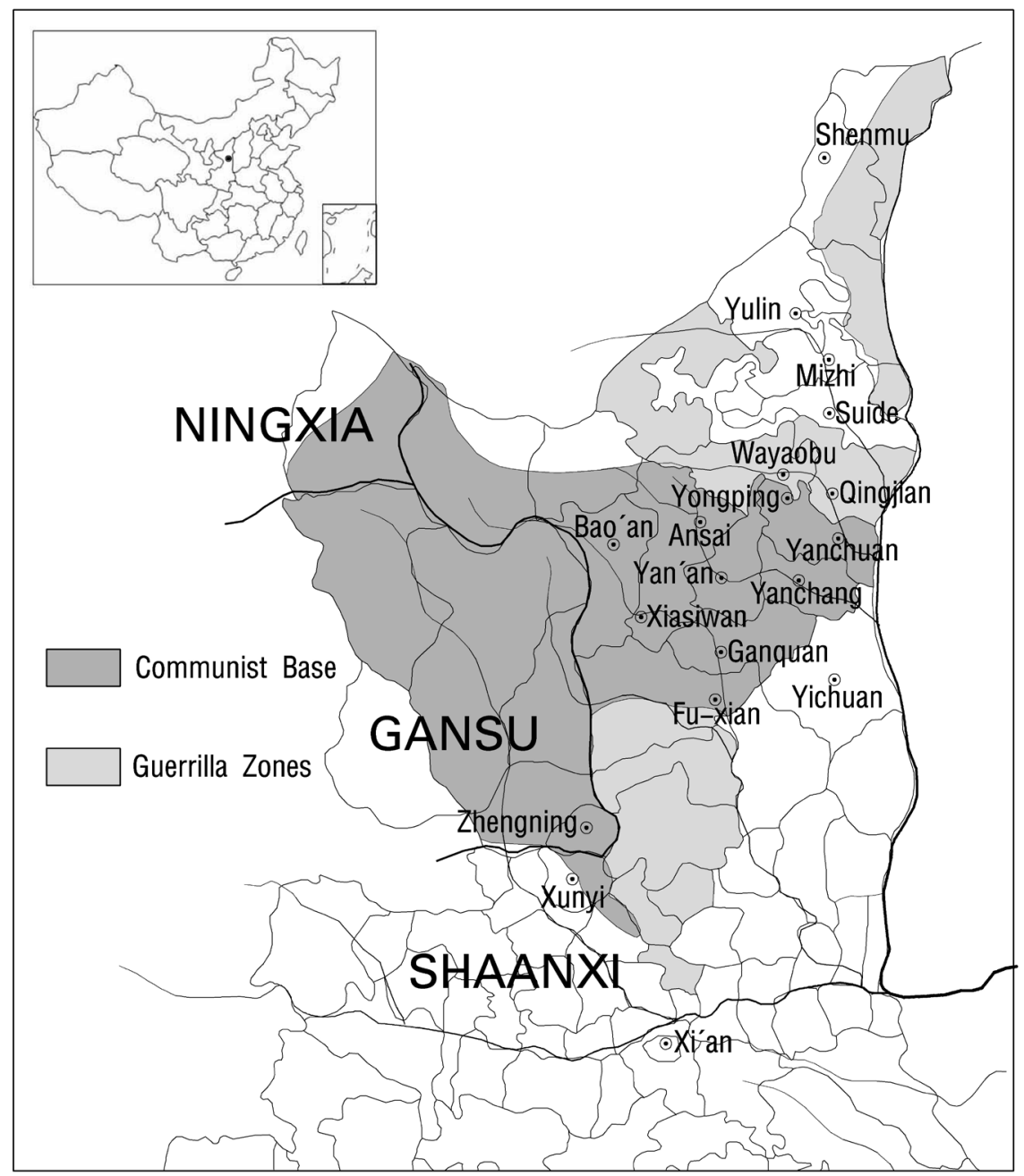

MAP 9. Shaan-Gan-Ning Border Region in June 1938, a year into the war with Japan. (Based on "Bianqu diaocha baogao," June 8, 1938, Guomindang Bureau of Investigation Archives, 270.15/810.)

sent an inspection team, which was greeted with great ceremony ${ }^{40}$ Slogans were painted on walls to support Generalissimo Chiang Kai-shek. The core areas under relatively secure Communist control were quite limited. When the Xi'an Incident broke out, the Red Army controlled only a few counties around Bao'an. Several sparsely populated areas in eastern Gansu had been occupied by He Long's army at the end of its Long March. After the Northeast Army withdrew during the Xi'an Incident, the Communists occupied Yan'an and most of neighboring Ganquan and Yanchang Counties. ${ }^{41}$ This was a much smaller area than the eventual twenty-three counties of the border region, and it included none of the richer counties in the northeast along the Wuding River (see map 9 above). 
As they set up their new "special administrative district," the Communists' first concern was security. In the former soviet areas along the Shaanxi-Gansu border, this took the form of eliminating "bandits." Bandit suppression began in the summer of 1936, but a year later the Communist leadership identified fortythree "bandit" gangs with 2,608 men in the soviet area, of which thirty-one with 2,147 men were allegedly eliminated. ${ }^{42}$ Two years later, there were still over forty gangs with roughly 4,00o members, including many seasonal outlaws, who spent much of their time as ordinary peasants. Now the party claimed to have eliminated twenty-six of these gangs and killed or captured roughly 1,500 bandits. ${ }^{43}$ Obviously, the revolution had not solved the problem of endemic banditry in Shaanbei. It was also clear, however, that the Communists had adopted the practice of previous regimes in classifying their political opponents as "bandits." In the words of Lin Boqu, Communist elder and head of the border region: "In the new ["democratic"] stage, the strongmen and landlords who were overthrown in the revolution have returned, and counter-revolutionary organizations have more opportunity to operate under the democratic system. The attempt of these reactionary powers to revive and arm themselves will not stop. Therefore bandit suppression is an important part of the revision of our work." 44

While Liu Zhidan had often used his personal connections and especially his Society of Brothers membership to win the support of local militia, the new leadership was far less forgiving of such local strongmen. In effect, the former "Communist bandits" (gongfei 共匪) now set about eliminating “militia bandits."

A classic example was Zhang Tingzhi in Bao'an. Zhang headed the local militia in a Luo River village not far from Liu Zhidan's home. The Zhang family owned large stretches of rich lowland at the point where the valley widened in the upper reaches of Luo. As many as two hundred retainers (menke 门客) cultivated the family's extensive landholdings. These vast holdings had been acquired by Tingzhi's great-great-grandfather, a drifter from Gansu with a gift for gambling and other semi-criminal activities. He is said to have acquired his wife in payment of a gambling debt and then to have finagled a job as a yamen runner in a nearby county. This minor government post generated enough wealth to buy up land in Bao'an. His sons and grandsons passed the military examinations under the Qing, the natural route to local status in this poor border region where Confucian education for the civil exams was unavailable. The Zhang family was unquestionably one of the established elite families in Bao'an, and it is not surprising that Liu Zhidan's family intermarried with the Zhangs and that Liu himself briefly joined Zhang Tingzhi's militia in an abortive attempt to convert it to his revolutionary cause. By 1935, Zhang was an implacable foe of the revolution and had taken a position in the local warlord's army. In 1937, he was a classic "local despot," advancing a slogan that opposed both the Communists and the united front: "Down with the Red Army and the White Army, Long live the Black 
Army." He was eventually driven from Bao'an but survived in the Guomindang areas to the north, leading his small band of militant anti-Communists to raid along the northern counties and even foment a brief mutiny in Wayaobu in 1937. Joining the Guomindang army, he survived until 1950, when he was executed as a "counter-revolutionary." ${ }^{4}$

In areas where the party shared control with the preexisting Guomindang administration, the policy toward local elites was a good deal more tolerant and flexible. The central principle was to organize on the basis of national salvation, targeting friendly armies, sympathetic militia members, women, and youth. Party members were enjoined to oppose oppressive taxation, encourage the wealthy to contribute to the resistance, and treat only the most recalcitrant as traitors. Though party members participated openly in patriotic political and propaganda activities, the party organization was to remain secret and be cautious and selective in recruiting new members. ${ }^{46}$ Party membership had increased significantly before and immediately after the Xi'an Incident, rising to 32,418 in May $1937 .{ }^{47}$ The composition of the party also changed. A systematic 1939 survey of party membership indicates that 71 percent joined in $1935^{-36}$, and since, as we have seen, the party was in retreat following the failure of the 1936 Shanxi expedition, most of these were ordinary peasants who joined during the radical expansion of the base under Liu Zhidan in 1935. Only 10 percent had even a primary education, and 41 percent were illiterate. ${ }^{48}$ Now the party wanted more disciplined and better-educated cadres, so it stipulated that the mass recruitment of party members should cease, that party members should be recruited individually, and that recruitment should not focus on relatives and friends of current members. ${ }^{49}$ The final prohibition indicates that past recruitment drives had focused on those most easily motivated: close friends and family members of current Communists.

With rising student opposition to Japanese aggression, the party turned increasingly to attracting young people. Even before the Xi'an Incident, the Communist Youth organization was transformed into a "non-party youth organization" advocating "democracy and freedom." In Guomindang areas, Communists were to eliminate their own separate organization and join legal patriotic organizations. In the soviet areas, Marxism-Leninism was still taught, but the emphasis was on culture, physical education, and military training. ${ }^{50}$ The Red Guards were transformed into Anti-Japanese Self-Defense Forces. There is little doubt that many young people responded to this appeal, and impressive numbers were enrolled in these organizations. ${ }^{51}$ Visitors routinely commented on soldiers in their midteens, or the independence and courage of the "little busybodies" in Yan'an. One enthusiastic Chinese visitor called Yan'an "the cradle of youth." ${ }^{52}$ Nationalist Party complaints that the Communists were misleading "gullible youth" with dancing and dramatic performances confirm the impression that the Communists were indeed winning the hearts and minds of the young. ${ }^{53}$ 
The most common conflict between the two rival parties was the competition to collect taxes. Shaanbei was bitterly poor, and a poor 1936 harvest left grain prices soaring and many without enough to eat. ${ }^{54}$ Still, a frugal and efficient local administration, plus a National Government subsidy of $\mathrm{CH} \$ 300,000$ to 500,000 for the Red Army, allowed the Communist regime to eliminate most of the old taxes, with the exception of the lucrative salt tax. Such taxes as the Communists collected were heavily progressive, amounting to forced contributions from the rich. ${ }^{55}$ In areas of dual control, however, the Guomindang authorities also collected taxes to support their apparatus, and most local "friction" between the two parties came over the issue of which regime had the right to tax. ${ }^{56}$

One critical element in the competition for local support and national legitimacy was the Communists' "democratic" appeal. In the twenty-first century, it is difficult to imagine a Communist regime as democratic. Autocratic rule by a single party that denies the freedom of speech and assembly violates all normal definitions of democracy. In 1937, however, the Communists launched a broad campaign to carry out local elections for village, county, and border region assemblies. After the Xi'an Incident, the Communist International had called on the CCP to transform its soviet into a "popular revolutionary government with a democratic foundation." ${ }^{57}$ Democratic governance was hailed as the "sacred mission" of the border region, whose purpose was to turn this "backward and ignorant" border region into a model for the entire country. ${ }^{58}$ As a precedent, the party cited Sun Yat-sen's support for self-governance in one province as a step toward nationwide constitutional governance. In conversations with foreign journalists in the spring of 1937, Communist leaders regularly cited these democratic elections to distinguish their regime from Chiang Kai-shek's autocratic rule. ${ }^{59}$

When elections were held in the fall, they began in villages, and the representatives selected in these elections chose delegates in indirect elections for district $(q u)$, county, and finally border region assemblies. The assemblies at each level chose the village, district, and county administrators. ${ }^{60}$ While all this appeared to be very democratic, the party was quite clear about the purpose of the exercise: "to thoroughly establish a democratic republican system and, in doing so, guarantee our party's leading role." ${ }^{11}$ While the regulations excluded only traitors, the interpretation of this term was broad. As the party explained, it was essential "not to let a single bad person get on the eligible list," and local organizers were enjoined to use the compilation of election rolls to identify "suspicious elements." ${ }^{2}$ There was no pretext of free and fair elections between competing parties. Lin Boqu, chairman of the border region, stressed that "in the villages, we must keep political power in the hands of the party." 63 The Communist Party was in control of the process, and the party cell prepared the list of nominees. The ground for village elections was first prepared in model districts, and elections could be delayed if a proper result was in doubt, which was easily monitored since this first election was 
usually carried out by a simple show of hands ${ }^{64}$ At higher and more important levels, party dominance was even more pronounced. Yanchang proudly reported the near-unanimous selection of the party's nominee for county magistrate "because all the delegates were party members." ${ }^{65}$ Nonetheless, for ordinary villagers unused to any voice in the selection of their leaders, the elections were undoubtedly a step forward. It is significant that when Guomindang supporters objected to the new regime, they argued that "even if popular," the independent Communist regime was incompatible with the idea of a unified modern nation. ${ }^{66}$

This, however, was precisely the purpose of the elections. While the elections may have helped nourish popular support for the new regime, they were far more important in protecting the border region's independence from Nanjing. Chiang Kai-shek still insisted that he should appoint the leaders of the border region, and in July he suggested such moderate Nationalist Party leaders as T. V. Soong, whom he thought the Communists might accept. ${ }^{67}$ The fact that they were in the process of electing representatives to the border region assembly allowed the Communists to reject these proposals as contrary to their commitment to a democratic republic and Sun Yat-sen's Three People's Principles. ${ }^{68}$ The elections, therefore, had less to do with establishing a democratic regime than with providing a rationale for an independent border region beyond the control of the Nanjing government.

There was, however, one election in the spring of 1937 that had real significance for local governance. In May, the party selected a new party committee for Shaan-Gan-Ning. The committee was a mixture of local Communists and such outsiders as Lin Boqu, who would become head of the new border region. As in any party election, the nominees were preselected, in this case by the deputy head of the Central Organization Department, Guo Hongtao, a key figure in the sufan campaign of 1935. Several of the targets of that campaign, including Gao Gang, were not nominated. In this election, however, the local cadres forced a significant display of inner-party democracy: Gao Gang received the most votes (eightythree) of any candidate, one more than Lin Boqu himself. Guo Hongtao, the man who had thrown Gao into prison, needed help from the Central leadership to even get elected, and in April he was packed off to lead the party movement in Shandong. ${ }^{69}$ Up to this point, Shaanbei had lacked anyone who could speak for the region in higher party circles. There is scant evidence that Gao ever saw himself as a representative of Shaanbei, and he certainly did not have the local reputation of the recently deceased Liu Zhidan. He was, however, indisputably a Shaanbei man, and this strong vote of support from the local party reflected its continued resentment of the sufan campaign and the resulting marginalization of the Shaanbei cadres. Following this election, Gao rose to lead the powerful security apparatus, the Shaan-Gan-Ning party committee, and then the party's Northwest Bureau, the most important regional post. Though his career would end with his purge and suicide in 1953, there was now at least one Shaanbei man at the center of power in Yan'an. 


\section{WAR AND THE UNITED FRONT}

On July 7, 1937, a local incident between Chinese and Japanese forces near the Marco Polo Bridge (Lugouqiao 卢沟桥) south of Beijing quickly escalated into full-scale war between China and Japan. With this, the War of Resistance began, the first stage in what would soon expand to become World War II. It was not at first clear that the conflict would spread, and several of Chiang Kai-shek's military advisers sought a local solution to the conflict. The Communists immediately called for a vigorous military response, and by the end of the month Chiang Kai-shek decided that further concessions to Japan were impossible and war was now inevitable. ${ }^{70} \mathrm{He}$ was not, however, ready to agree to the Communist terms for a united front.

As soon as war broke out. Zhou Enlai flew to Shanghai, then met with Chiang Kai-shek at his Lushan summer retreat. Again, the meetings with Chiang failed to produce agreement. As before, the key issue was command of the reorganized Red Army and leadership of the border region. Zhou found Chiang's offer worse than that of June, before the war broke out. In August, a draft agreement was apparently worked out, but then one of Chiang's anti-Communist advisers revised it in ways that were unacceptable. ${ }^{71}$ In July, Chiang had suggested such relatively progressive Guomindang members as T.V. Soong or Yu Youren (a leftist ally of the Shaanxi Communists in the 1920s) to head the border region; now he suggested a committed anti-Communist for the post. ${ }^{72}$ Obviously, the outbreak of war had not erased differences over the terms of the united front.

In August 1937, two distant events broke the deadlock and again demonstrated that Shaanbei would not determine its own fate. On August 13, rising tensions in Shanghai erupted into a major battle between Japan and Chiang's own armies, and the war now spread to China's economic center and the heartland of the Nationalist regime. At this point, total war with Japan became inescapable. ${ }^{73}$ At the same time, Chiang's agents were urgently seeking aid from abroad; and the Soviet Union, given its well-founded fears of Japanese hostility, was the most likely source of support. On August 29, a Sino-Soviet Non-Aggression Treaty was announced, and at the same time, arrangements were made for Soviet military assistance, the first tranche of which would start in November. In the early years of the war, the Soviet Union was the National Government's sole source of military assistance, ultimately providing over $\$ 173$ million in military equipment in exchange for Chinese agricultural products and raw materials. This critical equipment included 924 airplanes, 82 tanks, 1,516 trucks, 1,140 artillery pieces, 9,720 machine guns, 50,000 rifles, and the ammunition to go with them. ${ }^{74}$ By way of comparison, the Soviets offered the CCP $\$ 500,000$ in financial aid and delivered $\$ 150,000$ and no military supplies. ${ }^{75}$ With full-scale war with Japan now inevitable and Communists' Soviet patrons supporting the National Government, Chiang was prepared to accept the Communist terms for the united front. 
In the negotiations with Chiang Kai-shek in July, Zhou Enlai had presented a revised version of the Communists' four principles from February. They began with a promise to carry out Sun Yat-sen's Three People's Principles, thus endorsing the guiding ideology of the Guomindang; and they changed the Comintern's language of "democratic republic" to "a politics of people's rights" - again adopting a term sanctified by Sun Yat-sen. As before, the Communists promised to place their forces under the command of the central government, though the critical questions of command and political leadership remained unresolved. ${ }^{76}$ In August, the Guomindang finally accepted the Communist generals Zhu De and Peng Dehuai as commanders. The agreement established the basic principles of the united front. The Red Army would be reorganized into the Eighth Route Army of the central government's National Revolutionary Army, with offices for liaison and recruitment in Xian and other major cities. As a unit of the national army, it received a subsidy of $\mathrm{CH} \$ 500,000$ per month, in addition to $\$ 100,000$ for the border region. ${ }^{77}$ On September 23, the official government press agency published the Communist draft of the agreement. Chiang Kai-shek issued a statement on the following day, praising the Communists for abandoning their old ways, and the media hailed the new unity around Sun Yat-sen's principles. ${ }^{78}$ The National Government never officially ratified the accord, nor was there ever agreement on what its vague terms meant. As a result, the National Government consistently maintained that it had never legally recognized the Shaan-Gan-Ning Border Region. Nevertheless, there was now an official announcement that the border region had been established. Now the question became: What were the borders of Shaan-Gan-Ning? ${ }^{79}$

\section{DEFINING THE BORDERS OF THE BORDER REGION}

With the publication of the terms of the united front, all parties agreed that a Communist-dominated "special district" would exist, but the size and extent of that district were very much in dispute. The central government recognized a core area of six counties around Yan'an, and when the central army forces along the Yellow River joined the battle in Shanxi, the Shaanxi governor authorized a recruitment zone for the Eighth Route Army around this core. ${ }^{80}$ A Guomindang intelligence document from the time gave a fairly accurate picture of the actual situation on the ground: a core of six "Red" counties around Yan'an, surrounded by five "half-Red" counties to the north and south, then thirteen "partly Red" counties, plus a Communist presence in four counties of eastern Gansu (map 9).

Two of the areas represented zones that Communist armies had occupied only in the wake of the Xian Incident. When He Long's Second Army ended its Long March from western Hunan and reunited with the rest of the Red Army in the Northwest, most of its units remained in eastern Gansu. Once Zhang Xueliang's Northeast Army withdrew during the Xian Incident, the Red Army became the main force in this area. ${ }^{81}$ In late 1937 , these were recognized as a recruitment zone 
for the Eighth Route Army. The extension of Communist control was entirely a top-down process. As the secretary for the region put it, "The Red Army first established the soviet, then the party organization." 82 Gradually the Communists extended their political influence so that by the fall of 1937 , five counties in eastern Gansu were fully under Communist control, with Guomindang magistrates unable to assume their posts. ${ }^{83}$ The Communist presence north of the Wei in Guanzhong was also a product of military occupation following the Xian Incident. When the Northeast Army withdrew, it requested the Red Army to send its troops south in support, and Peng Dehuai led a unit to the Sanyuan area. As we have seen above, the party had long sought a base in the wealthy and strategic Guanzhong region, but it proved well beyond its military capabilities. Now this base on the northern fringe of Guanzhong became the border region's southernmost outpost, and after war with Japan broke out in 1937, it was both an assembly point for troops sent to the front and a recovery area for wounded soldiers. ${ }^{84}$ It provided a reliable link to the Communists' new office in Xian, and, in this relatively rich area, "contributions" from wealthy landlords were an important source of provisions for the Communist forces. ${ }^{85}$

War with Japan brought dramatic changes in military relations between the Nationalist and Communist armies. The Communists had long called for active resistance to Japanese aggression, and now their military leaders were anxious to prove their mettle in battle. Mao Zedong was more cautious, arguing persuasively that the Eighth Route Army was ill-equipped to confront the Japanese on the plains of North China and should confine itself to guerrilla warfare in the mountains. In September 1937, a well-executed ambush of a Japanese supply column at Pingxingguan in the hills of Shanxi provided a morale-boosting victory for the Chinese and a rare example of effective collaboration between Communist and Nationalist forces. For a time, both armies showed real enthusiasm for the united front. ${ }^{86}$ Slowly, however, relations began to sour. While the Communists were working effectively with Shanxi governor Yan Xishan and expanding their foothold in that province, Chiang Kai-shek's forces were defeated in Shanghai, lost the national capital in Nanjing (a military defeat that was followed by a horrific massacre), and finally abandoned the strategic central Chinese city of Wuhan. By the end of 1938, Japan had occupied all of the coastal and Yangzi valley cities where China's modern industry, finance, and infrastructure were concentrated, and Chiang had retreated to his wartime capital of Chongqing, far in the undeveloped interior. ${ }^{87}$ At this point, it was clear that the war with Japan would be long and costly. Chiang Kai-shek and his Guomindang supporters also realized that while their armies suffered successive defeats, the Communists were gaining strength in the north. The time had come to focus again on the Communist menace.

In the spring of 1939, the Guomindang circulated a new policy on "Guarding against Opposition Parties," followed by another that explicitly targeted the "Communist problem." The former noted the strong organization that allowed 
the Communists complete control of the border region and urged the Guomindang to "use organization to combat organization," while the latter stressed that the government "absolutely does not recognize the Communists' so-called 'Shaan-GanNing Border Region." 88 These policies were supported by a petition from unnamed local representatives of twenty-three Shaanbei counties who protested Communist tax collection, interference in education, misleading of young people, and a wide variety of violations of the principle that China should be a nation of "one ideology, one government, one leader." ${ }^{\prime 9}$ By now it was clear that despite Communists' promises that their "special district" would be under the direct guidance of the central government, and despite the dual administration in some counties with Guomindang magistrates operating alongside Communist personnel, Shaan-Gan-Nang was effectively becoming an independent state within a state. The Communist authorities were blocking all efforts to challenge the political, military, economic, or cultural initiatives of their new regime-ascribing such measures to a conspiracy of traitors and Trotskyites. ${ }^{90}$ For their part, the Guomindang intelligence services complained that the Communists' strict control of entry and the internal system of road passes made it impossible to get agents into the area. ${ }^{91}$ Now Chiang Kai-shek decided that the Guomindang should recover any areas not explicitly ceded to the Communists, and followed with orders to send capable magistrates to strengthen the local baojia tax-collection and security forces. ${ }^{92}$

At the same time, the Communist Party adjusted its position on the united front. Wang Ming, the young party leader in Shanghai in the early 1930 s and then the CCP delegate to the Comintern, returned from Moscow in late November 1937. He arrived in Yan'an with the imprimatur of the Comintern and briefly rivaled Mao as a leader of the party. In 1938, Wang Ming became the prime supporter of the party's united front with Chiang Kai-shek and the Guomindang and was sent to Wuhan to direct work in the Yangzi valley. When Wuhan fell, however, he lost his political base and much of the rationale for the united front. At the same time, Wang Jiaxiang returned from Moscow with news that the Comintern supported the more experienced Mao Zedong to lead the party. At a party plenum in November, Mao directly attacked Wang's slogan of "All through the United Front," and restored the emphasis on maintaining the party's independence..$^{93}$ By 1939, with Mao Zedong firmly back in power, both the Communists and Nationalists were ready to test the limits of the united front. As tensions mounted and armed conflict erupted in neighboring Shanxi and across the country, the Eighth Route Army commanders accused the Guomindang of turning its guns from the Japanese enemy to aim at domestic opponents, while Mao Zedong warned journalists from the Guomindang press: "We will not attack unless we are attacked; but if we are attacked, we will certainly counter-attack." ${ }^{4}$

All of this rhetoric reflected conflicts that had long been building on the ground. The war against Japan had brought a united front between Communists 
and Nationalists, but neither of the parties had any experience with political tolerance, and coexistence was challenging. Along the Shaan-Gan-Ning southern border, the Communists organized under the guise of a front organization, the National Salvation Society (Jiuguohui 救国会). The Guomindang resisted from its strongpoint in Yichuan, whose magistrate had been sent to Jiangxi for training in anti-Communist work. From Yichuan, the Guomindang tried, with only temporary success, to insert its magistrates into neighboring Yanchang and Yanchuan. The Communists mounted a vigorous resistance, eventually driving them off with organized mob activities. The Guomindang was accused of using education inspectors and ex-Communists as spies. ${ }^{95}$ As conflicts escalated, the border region authorities ordered the local magistrate to keep the initiative and seek out incidents to create friction. It went on to instruct:

From this time forward, if any incidents arise between you and the "friendly" [Guomindang] government, you should inform us as quickly as possible in a formal report to this office. You should, within reason, exaggerate the incident as much as possible, and you may even manufacture some facts. In addition, you should prepare a separate note informing us of the true situation and send it forward. In this way, we can on the one hand forward your formal report to the friendly government and on the other hand understand the true situation. Otherwise, they are always manufacturing facts and we are always looking for evidence, with the effect that we lose out in the war of words. ${ }^{96}$

We have a large collection that appears to contain summaries of the county reports of the actual incidents. What is most impressive is the petty nature of most disputes. Many (eighteen in total) come from Anding. In this area, the revolution had long pitted Communist-controlled "Red" villages against "White." Now the hilly southwestern part of the county, around the revolutionary martyr Xie Zichang's old home, was designated the Communist area, but the flatter and richer northeast was the Guomindang zone. Wayaobu, the major town and new seat of the county, stood at the juncture of the two zones and became the flash point of contention (see map 10). There was a branch campus of the Communists' Resistance University (Kangda) in Wayaobu, and several of the disputes involved the peremptory occupation of housing for the students. Both sides sought to organize in the other's area, with predictable disputes, accusations, and arrests. In general, when such agents were arrested, they were accused of being bandits, Society of Brothers members, or Japanese spies. The two sides competed for control of patriotic antiJapanese organizations, and joint banquets sometimes degenerated into mutual acrimony and cursing. Most tellingly, the Communists vigorously protested Nationalist propaganda, even when such "propaganda" was in fact accurate-for example, that Communist leaders, after the Xi'an Incident, had called for the execution of Chiang Kai-shek and had been blocked by the Soviet Union. The party was fully aware of the power of information, and it was determined to control the narrative in its territory. ${ }^{97}$ 


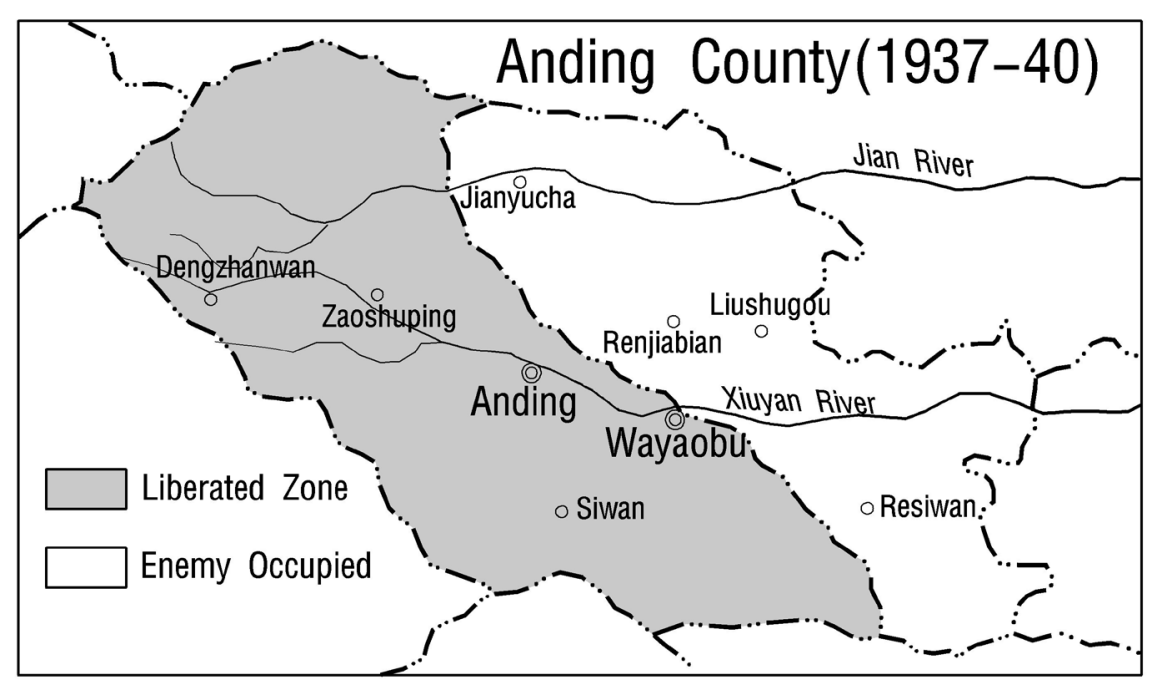

MAP 10. Separate Guomindang and CCP areas of Anding County, 1937-40. Wayaobu, the capital, is the dividing point in the middle. (Based on author's photo of map in Zichang County's Renjiabian [任家矿] Museum.)

With charges and countercharges of questionable accuracy flying back and forth, the rising tide of "friction" was building toward armed conflict, which broke out in earnest in early 1939. Xunyi County was in the southernmost extension of the border region, much resented by the Guomindang for its proximity to Xian, and also one of the richest parts of the border region and a key source of grain. An early survey of cultivated land shows 87 percent of the irrigated land in the entire border region in this one county. ${ }^{98}$ The area was along the Gansu border and not far from the old soviet base in Zhaojin (see chapter 3), but the local party organization was no longer strong. The main Communist presence was a branch campus for cadre training and a base for recovering Eighth Route Army casualties, which in late 1938 was moved to a different town, allegedly to escape Japanese bombing. The local Guomindang authorities resisted this intrusion and the burden that it imposed. Low-grade conflicts continued into the spring of 1939, with the Guomindang claiming that many of those relocated were not wounded soldiers but cadets in training. Soon the mysterious death of an Eighth Route Army soldier, for which both sides blamed the other, led to a major incident. The Communists organized protest demonstrations, arrested Guomindang security officers, and occupied the county seat. The Nationalists responded in force, driving off the Communists and inflicting 107 casualties against sixteen of their own. The Communist units retreated to a new base in a sparsely populated area near their old Zhaojin stronghold, and with this the southern extension of the border region in Xunyi and neighboring Chunhua Counties came to an end. ${ }^{99}$ 
The next test came 150 kilometers to the northeast in Fu-xian, its seat a true border town, and the county a contested area for both parties. In 1935, Mao's armies had fought their first major Shaanbei battle at Zhiluozhen, in the hills west of the small county seat. The Red Army's victory there was critical in protecting the Communist soviet to the north. The main road to Yan'an and then on to the Guomindang stronghold in Yulin passed through the county seat, and under the united front both parties sought to keep this vital artery open. In 1938, there were both Communist and Guomindang troops in the county, and for a time the two parties cooperated in the official Resistance Support Committee (Kangdi houyuanhui 抗敌后援会). In these border areas, the Communist strategy was to use antiJapanese organizations to recruit patriotic youth to their cause and undermine local elite domination of the tax and security apparatus. In this case, the chief Communist operatives joined the organization and gradually assumed control. In the countryside, Communist agents challenged the taxing authority of the local baojia. There is little doubt that local elites had used these bodies to enhance their power and enrich themselves, but the border region authorities criticized their own Fu-xian cadres for similar abuses and urged them to moderate their criticism of the Guomindang and to avoid putting their protests in writing. ${ }^{100}$ In the contest for local control, incidents became increasingly violent, with armed occupations, casualties on both sides, arrests, and forced confessions. Finally, in early 1940, Eighth Route Army forces occupied the county, arrested the magistrate, and brought him to Yan'an for trial. Concerned that the incident would break all communication along the road to Yulin, the Guomindang sued for peace, ransomed the return of its magistrate, and, in effect, conceded control of Fu-xian to the Communists. ${ }^{101}$

The Communists presence in Fu-xian was long-standing, and that local base was clearly a factor in their triumph. Eastern Gansu was another matter, and the results were quite different. With the exception of the immediate border with Shaanxi, the Communist regime in eastern Gansu was basically created from the top down by outsiders, primarily Long March survivors from the south. County regimes were established first, then rural districts, and finally village organizations. Since the cadres in charge were outsiders, they were often indiscriminate in their recruitment, and many local scoundrels, thugs, and opportunists found their way into the party. Members of the locally powerful Society of Brothers joined in large numbers when the party, at Mao's direction, treated it as a valuable ally. ${ }^{102}$ Once the united front had been established, the party targeted local military officers and students, neither of which proved to be reliable allies. ${ }^{103}$

A major problem that the party faced in this area was the unusually conservative local population. It was often reported that many of the men still wore the queues of the Qing dynasty and that nearly all of the women had bound feet. ${ }^{104}$ Almost none of the population was literate, so the party could not rely on schoolteachers or students in their local organization. When the Communists started promoting education, one county reported only four hundred students, a mere 
four of whom were girls. ${ }^{105}$ With a population devasted by the Hui Rebellion and natural disasters, land was plentiful, so the Communists' land reform policies had little appeal. What mattered was the exactions of the government, and this often worked to the Communists' disadvantage. With a growing local regime and a substantial army to support, cadres were forced to make significant demands on the population. Since the army, of necessity, supported the local cadres, selfserving corruption was a problem. When war with Japan increased the demand for recruits, coercive conscription prevailed as local cadres worked to fulfill quotas from above. ${ }^{106}$ When the regime required local government cadres to reclaim and cultivate land for their own support, they forced the local population to do the work for them or to provide loans. ${ }^{107}$

A damning report by a senior party official described armed cadres, in uniform and on horseback, carrying out their duties under military escort and acting like an occupying army:

In eastern Gansu, [cadre] work does not stay close to the people, it is opposed to the people. ... Everywhere you look there are coercive orders, arresting and fining people, peculation and corruption. ... [Then citing popular complaints:] "When you go to the people, on matters large and small, you immediately start to demand things." "In solving problems, you listen only to one side, so the people nurse grievances and become bandits." "Some low-level government organs are in the hands of bad people who oppress the poor." "Your methods are coercive: you assess four dou [forty liters], and if people balk you insist on eight. In conscription you ask, "Are you willing to fight the Japanese?" and if they say they are willing, you insist that they become a soldier, without exception. ${ }^{108}$

Following the 1939 Guomindang decision to deal with the "Communist problem," minor incidents mushroomed throughout the area. Since the Guomindang maintained a civil administration in Gansu, the conflict between the two parties typically amounted to competition for provisions between a Guomindang civil administration and the Communists' Eighth Route Army. ${ }^{109}$ Chiang Kai-shek decided that a military regime required a military response: armored cars and artillery were moved into the region. ${ }^{110}$ Along the road that followed the Jing River and connected Xi'an to Ningxia, the Guomindang assembled a force that in the winter of 1939-40 quickly recovered the county seats of Zhengning, Ning, and Zhenyuan Counties. The Society of Brothers sided with the Guomindang, and the Communists withdrew to sparsely populated hills to the north. ${ }^{111}$ Many of the businesses and even the students, who elsewhere were attracted to the Communists' progressive and patriotic appeals, withdrew to the Guomindang areas. ${ }^{12}$ As a result of these "frictions" the Communists lost over half of the population under their control in eastern Gansu. ${ }^{113}$

The biggest blow came in the spring of 1940 in Huan County, in the northwest corner of the border region, a vast and arid county where the population density of 12.7 people per square kilometer was less than one-fourth that of the counties 
along the Jing River. There, as elsewhere in the border region, local Communist and Nationalist authorities competed for control of tax revenues. They also had to deal with local power holders, including Zhao Laowu, whose family dominated a stronghold in the west of the county. The Communists initially tried to work with Zhao, then later targeted him and his local militia as "bandits," but that may have been because Zhao was remarkably successful in turning popular discontent over Communist exactions into opposition to the regime. ${ }^{114}$ In its 1940 offensive, the Nationalist authorities recruited this powerful local magnate to their side. ${ }^{115}$ When Zhao joined the effort to overturn Communist rule in Huan County he attracted support from all sides. One credible report counted 290 Communists in Zhao's local army, including 8o percent of its leadership. ${ }^{116}$ In August, however, Zhao was at his base in Huan County, far from the main Nationalist units along the Jing River. The Communists attacked and flattened his stronghold. ${ }^{117}$ Nonetheless, they had to admit that in Huan-xian "the people [laobaixing] rebelled against us." ${ }^{118}$ The fragility of the east Gansu regime was underlined later when 1,280 former Communists, including a significant number of Long March veterans, published an open letter announcing their defection to the Guomindang. ${ }^{119}$

The net result of these events was a significant loss for the Communists in the south and west of their border region. The Eighth Route Army commander in the area reported the loss of five county seats and forty-three townships. ${ }^{120}$ A 1944 summary of the size of the border region gave even larger and more precise figures: six counties, several thousand townships, a total of 30,640 square kilometers with a population of half a million-roughly a quarter of the area and population of the border region-was lost to the Guomindang in the course of this "friction" between the two parties. ${ }^{121}$ However, as the Guomindang was making major gains in Gansu to the west, the Communists were consolidating a more important position in the east.

Since the late Qing, the northeast had been the economic, political, and cultural center of Shaanbei. Its relative prosperity is indicated by a population density of forty-seven persons per square kilometer, more than four times the figure (eleven per kilometer) in the rest of the border region. ${ }^{122}$ It was the only part of the north with a local elite that included a respectable number of degree-holding gentry. Since the first decades of the Republic, the local warlord, Jing Yuexiu, was stationed in Yulin. In the mid-193os, the Guomindang headquarters leading the assault on the growing Communist movement was based in Suide. The area had the region's best schools, with half the number of students in the entire old border region. Shaanbei's first Communists came out of the middle school that Jing Yuexiu had established in Yulin and the normal school in Suide. In between was Mizhi, with a powerful gentry elite of landlords and Qing degree holders and a strong school system, including the best girls' schools, built up in the republican era. ${ }^{123}$ Though the Communists were active in this area during the united front of the 1920s, they were largely eliminated as the Guomindang and local elites regained control in the 
1930s. When the War of Resistance broke out, the Eighth Route Army established a presence here. Five counties along the Yellow River-Suide, Mizhi, Jia-xian, Wupu, and Qingjian—were designated a garrison area (jingbei qu警备区) for the Eighth Route Army as central government forces moved into Shanxi to fight the Japanese. ${ }^{124}$

Although this area was occupied by Communist troops and the Eighth Route Army was allowed to recruit here, the civil administration remained in Guomindang hands. The key official was He Shaonan, the Shaanbei commissioner based in Suide. His previous experience was in relief work, and in Shaanbei he aggressively sought relief funds from the central government. In his view, distributing relief was the most effective way to counter the appeal of the Communists' land reform policies. ${ }^{125} \mathrm{He}$ also controlled the education system and sent education inspectors to survey the area-an effort that the Communists treated as espionage-and reactivated the local baojia security apparatus. ${ }^{126}$ When the Communists sent activists to organize in the garrison area, He appealed to the central government for military assistance. ${ }^{127}$ There is substantial evidence that He Shaonan was a formidable opponent. Teachers and students were organized in Nationalist Party anti-Communist organizations; Communist defectors were recruited into "special work groups" to expose their former comrades; local security officials disrupted Communist efforts to collect taxes; landlords were encouraged to recover plots lost in the land confiscations of 1935-36; merchants and wealthy peasants were urged not to sell grain to the Eighth Route Army. All the evidence suggests that under He Shaonan the Guomindang was successfully resisting Communist control of the region. The opposition of the strong landlord gentry elite was to be expected, but the fact that the Nationalists were able to mobilize students and young people to their anti-Communist cause was particularly troubling. ${ }^{128}$

All of this changed at the end of 1939. As the Japanese army occupied Taiyuan, capital of neighboring Shanxi, and threatened the Eighth Route Army in that province, Wang Zhen's 359th Division was withdrawn to occupy Suide and allegedly defend the Yellow River. First came 2,700 men, then 5,000, and finally 18,000 crossed into Shaanxi. ${ }^{129}$ There is little doubt that in fact the Communists were compensating for their losses in the poor and distant regions of Gansu to the west by seizing this much richer area along the Yellow River. Indeed, early in 1939, the border region government had proposed a similar exchange to the National Government, explaining that the Gansu counties were far away and difficult to govern. ${ }^{130}$ Now, with the overwhelming military advantage that Wang Zhen's withdrawal brought, the National Government could only protest his troop movements as unauthorized retreat before the enemy, while He Shaonan organized student protests against the fiscal burden of the large Eighth Route Army garrison. ${ }^{131}$ After a series of conflicts between Communist cadres and Guomindang rural functionaries in which each side accused the other of violations, the Eighth Route Army demanded He's removal. When an officer for whom He Shaonan had 
provided a pass was caught allegedly smuggling opium, He was accused of corruption; driven from his post, he set fire to the arsenal on his departure. A replacement was appointed, but he too was driven off, and the area came firmly under Communist control. ${ }^{132}$

Throughout this process, Wang Zhen played a delicate double game. He recognized that some progressive elements in the local elite looked favorably on the Communist regime. The Japanese advance toward the Yellow River had aroused real concern, and the Eighth Route Army was the area's only defense. The Japanese had bombed Yanan in the winter of 1938-39, causing substantial damage but arousing predictable patriotic resolve in the local population. ${ }^{133}$ He Shaonan's aggressively anti-Communist regime had not been popular with all, and, as one CCP official put it, "We have used the gentry opposition to remove him." Needing competent officials to raise funds and run the government, Wang's new team retained some progressive and even "neutral" elements from the old regime. Not all local Communists were comfortable with this: the poor, inexperienced, and ill-educated local activists feared that these members of the old elite were "too capable." "The worker-peasant cadres and the old functionaries and intellectuals cannot work together. The gap between the two is very wide." In rural areas, for tax and security purposes, the Communists made sure they controlled the top of the apparatus, with 80 percent of the district lianbao (联保) heads newly appointed and two-thirds of them party members. On the other hand, 90 percent of the lower-level baojia officials were kept on from the old regime, usually rich peasants or landlords. ${ }^{134}$

By the summer of 1940, the Shaan-Gan-Ning Border Region was attaining its final shape. In July, Zhou Enlai met with Chiang's chief of staff, He Yingqin, in Chongqing and reached basic agreement on the borders that resulted from the year of "friction." Small adjustments were made on the northern and western borders, but the basic shape of the Communist zone was now established. ${ }^{135}$ As in the past, Chiang Kai-shek never formally approved this arrangement, nor did the National Government pass the required legislation, but the agreement held. ${ }^{136}$ The National Government recognized the reality on the ground by establishing a tight blockade around the border region. With Chiang's trusted general Hu Zongnan in charge, a defensive line of blockhouses with six layers of defensive moats and walls, scattered across a perimeter thirty to fifty kilometers wide, was constructed to contain the Communists in their northwestern refuge. ${ }^{137}$ (See map 11 for the agreed-on borders and the Guomindang defensive perimeter.) In the years to come, there would be international criticism of Chiang's use of prime troops to blockade the Communists instead of fighting Japan, ${ }^{138}$ but in 1940 attention had already shifted elsewhere. By the summer, a crisis was brewing over the growing strength of the Communists' New Fourth Army in the Yangzi valley. In January 1941, that controversy would erupt into an incident in which the Guomindang decimated the headquarters battalion of the New Fourth Army. ${ }^{139}$ With the 


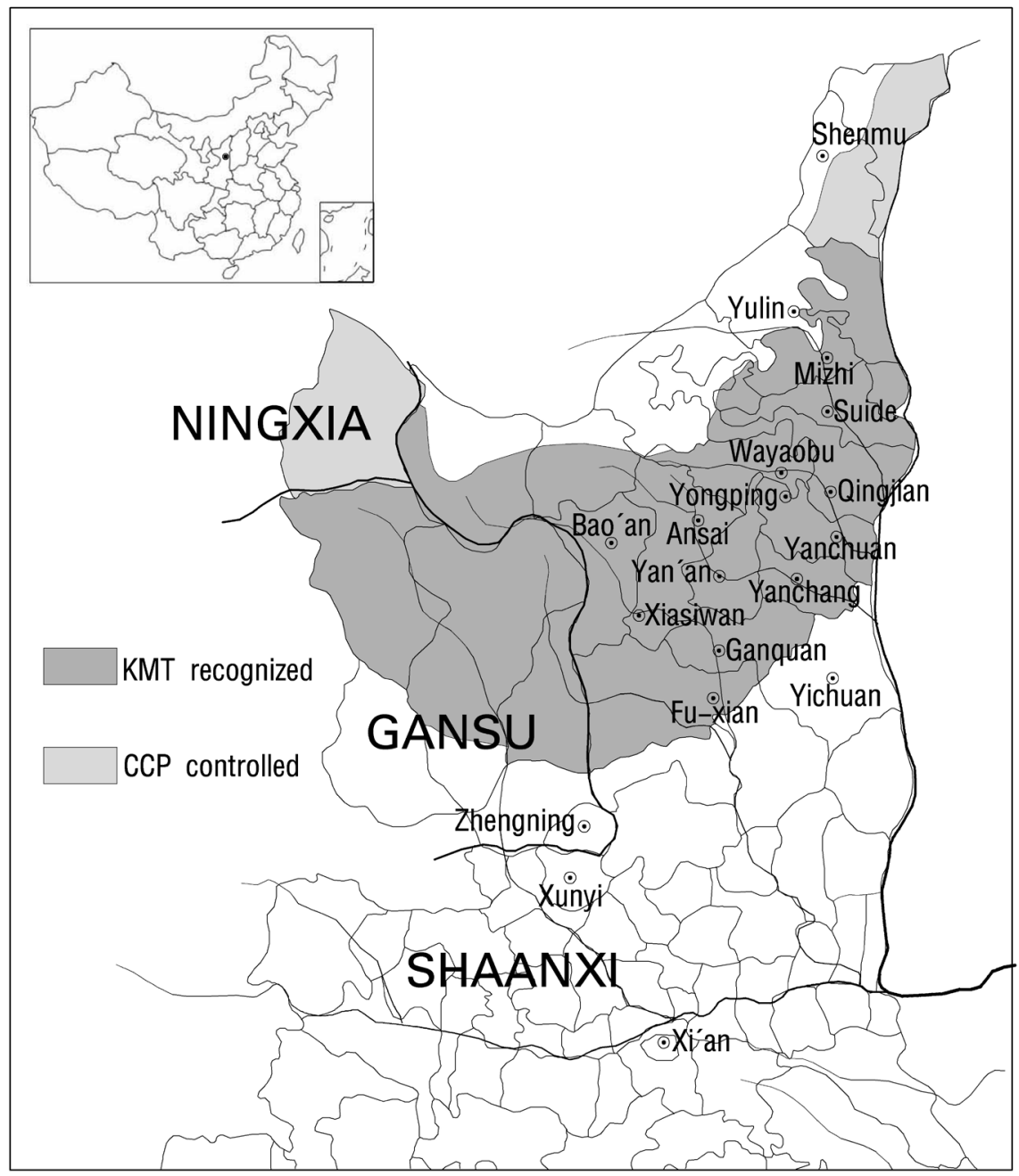

MAP 11. Shaan-Gan-Ning Border Region, July 1940. (Based primarily on He Yingqin to Chiang Kai-shek, July 16, 1940, in MGSL:ZG, 4:227-28.

Communist-Guomindang conflict shifting to other theaters, the shape of the Shaan-Gan-Ning Border Region was now secure-but what was the nature of the new regime within those borders?

\section{THE NEW REGIME}

The Shaan-Gan-Ning Border Region had an area of roughly 130,00o square kilometers and a population of 1.35 million in $1941 .{ }^{140}$ In a nation of some 400 million, this represented about 0.3 percent of China's population. The Shaanbei population 
density of roughly 10 people per square kilometer, compared to a national average of 39.5 , is an indication of the poverty of the region. ${ }^{141}$ Despite the tiny population, small area, and undeniable poverty, the region was hardly uniform, and its internal socio-economic variation was as important as its "backward" reputation. Not only was Shaan-Gan-Ning internally diverse, it also changed rapidly over time. The social and political transformation of the border region has been the subject of much excellent scholarship, and the manifold changes after 1941 are not my concern here. ${ }^{142}$ The subject of this study is the creation of the Shaan-Gan-Ning Border Region, and it is necessary to conclude with a brief sketch of the new regime as it was finally established.

Yan'an, it must be stressed, was a world apart. For all the political and scholarly focus on the locus of the party Center, Yanan was not Shaanbei. Before the Center moved there in 1937, it was a small frontier town, long eclipsed by Yulin and Suide to the east. Throughout the war, Yulin remained in Guomindang hands, and Suide was He Shaonan's base until he was driven off by Wang Zhen. Yan'an became the Communist headquarters by default, and to a large degree it was a blank slate on which the party could draft the contours of its new state. The party was never active there during the long process of revolutionary struggle. In the course of the war against Japan, Yan'an's population increased at least tenfold, with the addition of party cadres, officials, soldiers, and thousands of students who flocked to Resistance University and other schools. ${ }^{143}$ The vast majority of these were outsiders, many educated youth, and there was an obvious gap between them and the local population. As Nym Wales put it: "The North Shensi [Shaanxi] villagers are considered among the most backward in China." ${ }^{144}$ When her husband interviewed a party propaganda specialist, "He tended to despair of doing well in Shensi; the human material seemed far poorer to start with." ${ }^{145}$ Most of the young people who streamed into Yanan would study at one of the schools there. Kangda was the most famous, but its intensive six-month training course first taught Red Army soldiers and only after 1938 included more civilian youths. Nearly all of these were sent for military or support work on the front lines. They came, they studied, and they left for the front. Few had much contact with Shaanbei. For Shaan-Gan-Ning, the Shaanbei Public School (Shaanbei gongxue 陕北公学) was more important. Half of its graduates were posted to the border region. ${ }^{146}$

With its largely outsider population, Yan'an's public face in the early war years fully supported the united front. Slogans painted on walls, portraits of Sun Yat-sen and Chiang Kai-shek, and patriotic propaganda about the need for unity against Japan were an integral part of the Yan'an discourse. Elsewhere the reality was different. According to one Zhidan (formerly Bao'an) County report on the early war years, "As a central area of the Border Region, there is little united front work in Zhidan." It then went on to describe its vigorous suppression of the local "die-hard elements." ${ }^{147}$ Outside of Yan'an, the party was less concerned with preserving the united front than with eliminating its political opponents. It 
was a process that easily overlapped with the everyday public security practices of the state.

Along the borders both north and south, security was always an issue. In many central counties, the courts were largely concerned with civil cases, especially marriage and land disputes. On the borders, however, criminal cases prevailed by a factor of fifteen to one: banditry, gambling, opium cases, theft, assault and flight. ${ }^{148}$ Some of this was a persistence of long-standing patterns. Bandits always thrived in areas where they could flee to the mountains or a neighboring jurisdiction. The soldier-bandits that the Eighth Route Army suppressed in the Huanglong mountains to the south of the border region were certainly of this type. ${ }^{149}$ Others were political opponents, like Zhang Tingzhi in Bao'an or Zhao Laowu in Huan-xian, local magnates who, as we have seen, became opponents of the Communist regime and often sought refuge in neighboring Guomindang territory. Though Liu Zhidan had built his army from bandit gangs and though Communist doctrine had once treated bandits as oppressed peasants whose poverty drove them to criminal activity, once in power the Communists suppressed banditry as vigorously as any government. Bandits, in general, were not popular: peasants regarded them as a scourge, often neer-do-wells who avoided honest work. ${ }^{150}$ It is not surprising, therefore, that the Communists, in effect, politicized the term: painting all of their opponents as bandits and treating banditry in border areas as the work of Guomindang or Japanese agents or the criminal habits of the old society that prevailed beyond the area of Communist control. Warnings against "bandits and traitors" run through the documents of this period. ${ }^{151}$

The change in Communist policy toward the Society of Brothers is particularly notable. The Brothers were hardly a "secret society" in Shaanbei-most people knew who was a member-and the Communists had long appealed to the Brothers. After Mao moved to Bao'an and the Shaan-Gan border, where the society was particularly active, he issued a famous appeal to the Society of Brothers, noting its prominent role in the 1911 Revolution and aid to the Communist movement. He praised Liu Zhidan and Xie Zichang as "exemplary members of the Society of Brothers." The organization's tradition of "striking the rich and aiding the poor" was compared to the Communist program, and Mao promised legal status for the Brothers in the soviet areas and a reception bureau to welcome its leaders. ${ }^{152}$ That was the party's public face. One year later, the party drafted an internal directive on work with the Society of Brothers, now described as having a "strongly conservative, superstitious, feudal, and reactionary character." While the party should continue to court the society and recruit its members in Guomindang areas, within the border region all organizational forms of the society were prohibited in order to "eliminate opportunities for open activities."153

Eliminating the Society of Brothers proved to be a difficult task. In some areas, Brother bands trafficked in opium, now banned in the border region but a common sedative in Shaanbei society. ${ }^{154}$ Far more troubling was the substantial 
number of Brothers in the party. In one district, 115 society members were uncovered, 64 of whom were party members. Even more troubling was the fact that 35 had joined the society after they were already party members. ${ }^{155}$ Another pair of villages had 34 party members, 32 of whom were Brothers. ${ }^{156}$ The second case suggests that the party was recruited from preexisting Brother networks; but the case where many joined the society after they were already party members suggests that the Brothers were more successful at infiltrating the party than vice-versa. In effect, in these initial stages of regime formation, local webs of influence were successfully competing with the party for power in Shaanbei's rural communities.

The most important challenge that the party faced in these first years was creating a reliable rural apparatus. The new regime's local cadres were ordinary peasants who had joined the revolutionary movement, and they included many with undesirable habits. One credible Guomindang intelligence report criticized the gambling and hooligan behavior among county cadres but admitted that rural cadres were disciplined and worked hard for the new regime. ${ }^{157}$ The new regime made significant efforts to eliminate lifestyle practices of which it disapproved. As part of the "anti-traitor" campaign, it particularly targeted gambling, opium sales, and trafficking in women and children. ${ }^{158}$ Before they were displaced, Nationalist Party officials disparaged the CCP's local cadres from the "worker-peasant class: their education is slight and their thinking is simple-minded." ${ }^{59}$ The new party Center would not have disagreed. When the Center arrived, Shaan-Gan-Ning was "originally a backward, ignorant region on the border of three provinces." 160 Returning from the Soviet Union in late 1937 on the same plane with Wang Ming was Chen Yun, who was immediately put in charge of the Organization Department to bring a new level of Leninist discipline and a Stalinist commitment to the principle that "cadres decide everything." 161 In 1939, the Shaan-Gan-Ning Organization Department produced a set of statistics on county and rural cadres: only 2.49 percent had a middle school education, 10.42 percent had some primary education, 45.6 percent knew only enough characters to read a newspaper, and 41.26 percent were illiterate. ${ }^{162}$ These disappointing figures on education levels reflected the history of past recruitment: 71.2 percent had joined the party in 1935-36, mostly as Liu Zhidan's forces surged through the area in $1935 .{ }^{163}$ This was the rural apparatus of poor peasant activists that the new regime inherited and set about to transform.

This apparatus differed from the structures of the old regime in several important respects. It was larger and more successful in penetrating rural society. A recent detailed study of Guomindang rural administration notes that only during the war, and partly to handle such matters as conscription, was the Nationalist apparatus extended to the district (qu) level. ${ }^{164}$ The Communist apparatus extended even closer to the peasants, to the "township" (xiang) and administrative village levels, and cadres down to the township level were salaried and "divorced from production." 165 In the entire border region, there were only 179 districts, but 1,063 townships for a total of $1,242 .{ }^{166}$ This meant, in effect, a sevenfold increase over 
the size of the Guomindang rural administration. In addition, the Guomindang apparatus was self-funded, meaning that the local baozhang (the key tax and security person) kept a portion of the taxes and fees that he collected, so rural functionaries behaved more like independent contractors than employees of the state. When they first took over, especially in the eastern counties with an intact Guomindang apparatus, the Communists simply appointed their cadres in the old apparatus and allowed them to keep a portion of tax receipts for their own expenses. ${ }^{167}$ Throughout the region, rural work was initially ad hoc and even chaotic, a "guerrilla-style of work" with few records or supervision. As Chen Yun's Organization Department took control, the regime set up its own system with "meetings, reports, on-the-spot investigations, work reviews, and a division of labor in leadership." 168

One reason for the larger apparatus was the expanded range of activities of the local administration. The archival record demonstrates a close attention to the following aspects of local work: grain requisition, conscription, "anti-traitor" work, opium suppression, education, literacy, production, cultivation for soldiers' dependents, legal affairs, marriage and divorce, and consumer cooperatives. ${ }^{169}$ The highly progressive tax system and conscription that targeted families with more than one son required close knowledge of individual families and their resources. One local official suggested using popular customs like "dropping in on people" (chuan menzi 串门子) or using kinship relations to become familiar with everything. The key was to combine "public surveys and private visits." ${ }^{170}$ For this sort of work, the party required loyal cadres with good local knowledge, the respect of their community, but above all the ability to produce results. The shift from a local apparatus dominated by landholders with some reputation meant, in the words of one cadre, a shift from service by those with "face" to work by those with the ability to get things done. ${ }^{171}$

The expanded agenda of the new regime made competent rural cadres more important than ever. The largely illiterate party members from the soviet period were often not up to the task, so expanding education was essential. Initially, the party relied on teachers from the old schools, but some had suffered during the revolution and were reluctant to serve, and others were communicating the wrong political message: "In the worst cases, if you ask primary students which is better, the Guomindang or the Communist Party, some say the Guomindang." 172 This was unacceptable. To train a new generation of leaders, an expanded education network was necessary, and every work report recorded progress on this front. The foundation was low, the progress was slow, and setbacks were common. But there was progress. In 1937, there were only 320 primary schools with 1,600 students in the border region. By 1939, there were 890 schools, and in 1941, 1,341 schools with 43,846 students. Conflicts with the Guomindang, the end of the subsidy, and the elimination of smaller schools in isolated villages reduced the number to 723 schools in 1942, with about 30,000 students. ${ }^{173}$ In just five years, the Communists 
had achieved a nearly twentyfold increase in the number of students. Despite the substantial increases, attendance rates were low. In 1939, Gao Gang reported that 90 percent of the population was still illiterate, and only 20 percent of the schoolaged children were in school. ${ }^{174}$ Female participation lagged terribly: in Zhidan only 172 of 845 students (barely 20 percent) were girls. ${ }^{175}$

We should realize, however, that although the Communists' commitment to education and popular literacy was genuine, the immediate need was not an enlightened peasantry but basic literacy and numeracy, the mental tools necessary for administrative cadres and soldiers. Beyond that, education mostly instilled patriotic values, the virtues of the Communist Party, and the basic class consciousness of Marxism-Leninism. Peasants were quite cognizant of these purposes, seeing school as nothing more than preparation for life as a soldier or cadre. As a result, most families resisted sending their children to school. ${ }^{176}$ Peasants understood that learning “is for the sake of the state [gongjia 公家]." School attendance also deprived families of critical farm labor. This was especially true because in Shaanbei, school attendance started very late. In one survey of 115 primary school students, 111 were over the age of thirteen and half were already married. ${ }^{177}$ Rather quickly, however, the regime succeeded in training young people with the skills needed to be a local cadre, and as they were promoted up the ranks, each year a county would send ten or twenty of its functionaries to Yan'an for further study. ${ }^{178}$ Thus was built the apparatus to carry out the program of the new regime.

Communist-style democracy was an important part of this process. In the northeast counties, election participation was very high, averaging around 90 percent, in part because villages competed for representation at the next higher district level, from which tax assessments would come. It was claimed that with this new level of political participation, the quality of cadres improved. ${ }^{179}$ Village elections every six months provided ample opportunity for peasants to assess local leaders, and the high rate of cadre turnover indicates a close attention to selecting men (and they were all men) who could perform the tasks of the party and also work effectively with their peasant constituents. In 1940, Zhidan County reported that twelve of thirty-eight local cadres had been removed; and in the first two years, 70-80 percent were either promoted or demoted. ${ }^{180}$ In Suide, fifty of fiftyeight were reassigned. ${ }^{181}$ Statistics for the entire border region indicate that among cadres at the district level and above, 1,354 were promoted and 5,612 attended various types of training sessions. ${ }^{182}$ The party made sure that it was attentive to popular sentiment, so work reports routinely included a section on popular complaints (guaihua 怪话), and there is every indication that future work and cadre assessment took account of these complaints. ${ }^{183}$ In the Organization Department cadre statistics, of 1,316 purged from the party, 301 dismissals (23 percent) were for "not working," 204 (15 percent) were for corruption, and 93 (7 percent) were for gambling or opium. ${ }^{184}$ One abuse that the party was determined to eliminate was cadres taking married women as second wives, a practice that was strictly prohibited 
TABLE 2 Tax burden of new regime

\begin{tabular}{|c|c|c|c|c|c|}
\hline & 1937 & 1938 & 1939 & 1940 & 1941 \\
\hline Administrative and army personnel & 14,000 & 16,000 & 49,000 & 61,000 & 73,000 \\
\hline External support: percent of budget & & 50.6 & 85.8 & 74.7 & \\
\hline Grain tax $(\text { dan 石 })^{\mathrm{a}}$ & 14,000 & 15,000 & 60,000 & 100,000 & 200,000 \\
\hline Grain tax as percent of harvest & 1.28 & $1.27^{\mathrm{b}}$ & $4.72^{\mathrm{b}}$ & $7.35^{\mathrm{b}}$ & 13.8 \\
\hline
\end{tabular}

a One dan $=300$ jin = ca. 150 kilograms.

${ }^{\mathrm{b}}$ Percentage assumes uniform increase in harvest between 1937 and 1941.

SOURCE: Li Weihan, Huiyi yu yanjiu, 2:500-501.

"to eliminate popular discontent."185 Obviously, such statistics can be interpreted in different ways. On the one hand, they show significant abuse by Communist cadres. On the other hand, they indicate that people were objecting to such abuse and the party was responding.

In an area with no experience in democratic governance, the party struggled to establish its own definition of "democracy." With democracy promoted as an alternative to the old regime's arbitrary ways, many understood democracy to mean doing as one wished. Peasants used "democracy" as a reason for resisting taxes. Wang Zhen confronted such complaints in the northeast, where people protested, "If you are going to issue orders, why talk about democracy? You speak about democracy, but you still send down directives." Others made the familiar complaint that Communist democracy involved too many annoying meetings: with orders from above and resistance below, it was difficult to get anything done. The pressure on cadres was particularly great: meeting the demands of the state meant imposing burdens on friends and neighbors. Fear of offending people was the most common reason for avoiding cadre work. ${ }^{186}$

Naturally, the strongest complaints were against the growing burden of the new regime. When the Yan'an regime was established in the wake of the Xian Incident, the small local apparatus, substantial National Government subsidy, and heavy reliance on "guerrilla-style" demands on the wealthy kept extractions from the local population to a minimum; but all these factors changed in the following years. As detailed in table 2, the number of administrative and military personnel "divorced from production" increased dramatically when Wang Zhen's troops were recalled to the northeast. Then the National Government subsidy was halted in July 1940. With these changes, the tax burden on the border region population increased dramatically.

To meet the deficit and generate hard currency to buy medicine and essential supplies from Guomindang areas, the government required peasants to use their draft animals to transport salt from the fields in the far north to the Guomindang areas in the south. The loss of time in the fields and injury to draft animals on the long journey made it an extremely unpopular policy. ${ }^{187}$ Unsurprisingly, 
complaints quickly followed: "When you harvest chives, you need to wait a few days before you cut again. Now the burdens come more rapidly than the harvesting of chives. We haven't finished paying the grain requisition and then comes the borrowing for salt transport. We haven't finished paying these 'loans' and there comes a call for shares for cooperatives, savings certificates, education, grain, and expenses. Before these are collected it is time for the second collection of salt transport loans." 188

There were many complaints against coercive behavior by the army. The demands of the war brought conscription with an intensity never before seen in Shaanbei. In 1938, the recruitment plan called for five thousand soldiers in two months, equivalent to the entire Shaanbei Red Army before the arrival of the Long March. ${ }^{189}$ Women were naturally anxious about losing sons and husbands to the army, beloved family members and vital workers in the fields. They were targeted to assist in recruitment-presumably urging women not to resist losing their sons and husbands. In January 1939, border region chairman Lin Boqu reported that thirty thousand men had been mobilized for the front, half of whom had come from the local self-defense forces, which served as a feeder for the regular army. ${ }^{190}$ Every county had its local quota, and local cadres scoured the villages for recruits. The process was supposed to rely on persuasion, but there were many reports of coercion and beatings of those who resisted. ${ }^{191}$ Local work reports suggest that desertion was a major problem, and the use of force in capturing AWOL soldiers seems to have been more common than with conscription. In 1940, Zhidan County reported that 182 deserters had been returned to the army, which represented almost half of their total recruits. Another county reported the "not small" cost of an operation that had caught 156 deserters but caused others to flee, some of whom were killed in pursuit. ${ }^{192}$

In handling complaints about the policies of the new regime, there was a distinct difference between the old soviet areas and the former garrison areas that Wang Zhen occupied in 1940. These differences reflected the enduring contrast between the poor and sparsely populated region west and south of Yan'an and the wealthier, better-educated northeast with its powerful gentry elite. In the former soviet areas, people were generally willing to accept the demands of the new state as long as they were fair (gongping 公平). ${ }^{193}$ In the area around Suide in the east, skeptical landlord and pro-Guomindang elites posed a greater challenge. When Wang Zhen took control of the area, he allied with progressive members of the local elite to isolate and expel the Guomindang commissioner, He Shaonan. In 1940, competent progressive or "neutral" elements from the old regime were needed for technical work: accounting, tax collection, forestry, water control, and economic development. Local Communists were skeptical about working with these more competent elites. Initially, routine work was carried out by personnel from Wang's 359th Division, but the long-term solution involved developing local cadres who could work with the old elite and gradually replace them. 
As elsewhere in the border region, elections in the northeastern "garrison area" were an important part of the legitimation process, but the 1941 elections were different from those of 1937. As usual, the party prepared carefully and even delayed the elections to complete their propaganda work. ${ }^{194}$ The results of the election were generally positive, especially in the scattered areas where the party had carried out land reform during the soviet period. Here complaints mostly concerned the distribution of the tax burden, and assembly discussions were lively. The authorities were pleased that after the elections and the open airing of grievances, the quality of local cadres improved, and some were removed. The most striking differences were in the county assemblies. Recall that in the 1937 elections, the party's domination of the assemblies was absolute. Now in Mizhi there were intense debates between Nationalist and Communist representatives in the county assembly. ${ }^{195}$ As the border region expanded to include wealthier regions of the northeast with their entrenched gentry elites, the united front took a new form. In the west, local strongmen like Zhang Tingzhi would be attacked and eliminated as "bandits." In the counties around Mizhi and Suide, the party worked with the educated and technically competent members of the elite that it deemed progressive. Soon there would be new elections for the border region assembly, and some of these progressive educated elites would join the assembly in Yan'an. One of the most prominent was Li Dingming, a local educator, Chinese medicine practitioner, and cousin of the Nationalist general Du Yuming. In Yan'an, Li was elected vice-chair of the border region and became one of the foremost exemplars of the Communist united front policies. In the fiscal crisis of 1942, he proposed the policy of "crack troops and simple administration" (jingbing jianzheng 精兵简政), which became a signature example of frugal wartime administration. ${ }^{196}$

With the inclusion of the northeast "garrison area" within the Shaan-Gan-Ning Border Region, the Communists not only added a richer area to support their army and administration, and a better-educated population to provide cadres to enhance their rule, they also added an area with a social structure that more closely resembled the rest of North China. The original soviet on the ShaanxiGansu border was a sparsely settled land of small and widely dispersed villages, largely populated by recent migrants with weak lineage structures. Always poor, it had never fully recovered from the devastation of the Muslim Rebellion. A land of bandits and militia bands whose tightest social glue was the Society of Brothers, it provided a fertile breeding ground for Liu Zhidan's guerrilla forces. Here the party Center built its base, first in Liu's home county in Bao'an and along the Gansu border, then in Yan'an following the Xian Incident. But it was only with the incorporation of the garrison area around Suide that Shaan-Gan-Ning achieved its final form. And it was only with that addition that the party learned to confront, include, and control the kinds of local elites that they would soon encounter in Shanxi and North China generally. 
The addition of the garrison area also exposed another aspect of the Yan'an era. The northeast had been the site of the earliest growth of the Communist movement in Shaanxi, especially in Yulin Middle School and Suide Normal, where the founders of the Shaanxi party had taught, and in the well-developed school system of Mizhi. In that early stage of the movement, the leftist agenda stressed a general assault on conservative authoritarian principles in education and patriarchy in gender relations. As we have seen in chapter 2, allowing young women a more visible and public role-walking the streets to school, cutting their hair, and wearing skirts-was an important part of this movement, to the extent that more political elements of the party complained that students were "drunk with maudlin poetry and thoughts of love." 197 In its advocacy of education for women and free choice in marriage, Shaanxi's early Communist movement embraced the ideals of the May Fourth Movement. But gender was always a sensitive flash point of the Chinese revolution, and just as the modest reforms of the 1920 incited conservative reproach, the 1939 attack by hostile Shaanbei local elites included the charge that traditional gender norms were threatened by young men and women mixing in Yan'an, where "free love" was allegedly practiced and VD spread unchecked. ${ }^{198}$ Yan'an, of course, was a world apart, with a gender ratio of eight males to each female in the early 1940s, and a relatively relaxed attitude toward extramarital sex. ${ }^{199}$ Gender relations in the Shaan-Gan-Ning Border region as a whole were governed by a different dynamic.

The judgment of most past scholarship has been that the relatively conservative values of Shaanbei caused a retreat in commitment to women's rights when the party Center moved to Shaanbei. ${ }^{200}$ Ding Ling, with her famous 1942 essay on International Women's Day, certainly felt that the party had compromised its early commitment to gender equality. ${ }^{201}$ But with power firmly in the hands of the Long March veterans, Shaanbei was hardly responsible for the shift. The party's military priorities were more important. The founding of the Shaanbei soviet was largely a process of military conquest, and the establishment of the new regime was predicated on secure military control. In the south, some women had joined the army, and the Long March included a women's regiment; but those women became part of the disastrous Western Expedition where most were killed and those captured were married off to the local Muslim population. ${ }^{202}$ None reached Shaanbei. In Shaanbei, women mostly served a male military: encouraging their men to join the army (or at least not discouraging them), making shoes and socks for the soldiers, sometimes washing and darning their clothes. Women could not divorce husbands in the army, and the regime attempted (with some success) to ensure that they received help to cultivate their fields. ${ }^{203}$ Within the army, the sexual abuse and even rape of women was certainly less common than in warlord forces, but it did occur, and, as we have seen, such particularly valuable political officers as Gao Gang were only lightly punished for their transgressions. Perhaps the most notable measure of the party's priorities was the care it displayed for the conjugal needs of army officers. Eighth Route Army regulations stipulated that 
only regimental officers twenty-eight years or older with five years' party membership were permitted to marry. ${ }^{204}$ The policy clearly favored senior officers, and there are numerous accounts of Long March veterans, including Mao himself, discarding their peasant wives in favor of the young women who flocked to Yan'an during the war. ${ }^{205}$

As elsewhere in Asia, the earliest stages of the Chinese revolutionary movement were supported by an international group of professional revolutionaries who found that the best way to avoid colonial intelligence services was to travel first class. ${ }^{206}$ When Mao and other Communists formed their soviet bases in China's rural hinterland, the Communist movement moved to a new stage. Now simple living in harsh circumstances became the rule. In some respects, these conditions prevailed in Yan'an as well, for Shaanbei was poor even by the standards of the southern soviets. For the young people who flocked to Yan'an during the war against Japan, dirt caves and meatless meals were part of its appeal. In Shaanbei, simple living, meagre government salaries, and egalitarian poverty were the rule-and part of what distinguished the Communists from the Nationalist Party. This dedicated life of undifferentiated patriotic poverty was fundamental to Yan'an's identity as a revolutionary holy land. The one area where a clear hierarchy prevailed was in access to women. As the leftist intellectual Wang Shiwei noted to his peril, the highly skewed maleto-female ratio made access to the young women of Yan'an a significant source of tension. ${ }^{207}$ In this context, the party guaranteed its favored leaders preferential access to sex. They had endured years of military conflict, and the top leaders had survived the harrowing Long March retreat. Now at last they were safe and secure in Yan'an. They deserved a young female companion for a good night's sleep.

Beyond the special circumstances of Yan'an, this policy limiting marriage to the army's top leaders had its greatest impact in the northeast. There is a favorite rhyme in Shaanbei, describing the special features for which the eastern counties were famous: "The girls of Mizhi, the guys of Suide; millstones from Qingjian, coal from Wayaobu." It is not clear how old this ditty is, nor what exactly recommended the women of Mizhi, but it is certainly true that in the republican era, the county had the best girls' schools in Shaanbei. This advantage carried into the Communist era. Indeed, it seems to have increased, with the number of boys in school falling while the number of girls rose. The reason: education improved their chances of a favorable marriage. ${ }^{208}$ The report does not say whom they were marrying, but Mizhi is also called "father-inlaw's county" (zhangren xian 丈人县) because of the large number of Eighth Route Army officers who found a bride there. ${ }^{209}$ So the progressive promotion of female education in the northeast ended up serving the revolution in new and unexpected ways. Women's education, in the end, provided wives for the army.

In 1937, the American reporter Nym Wales (the pen name for Helen Foster Snow) visited Yan'an. She spent most of her time interviewing the Communist leadership, and her brief sketches of the leaders would, for the first time, introduce them to the 
world. An appendix to her book includes capsule biographies of seventy Chinese Communist leaders. None is from Shaanxi. ${ }^{210}$ She met with all the top leaders, and they in turn suggested others whom she might interview. She was the wife of Edgar Snow, whose Red Star Over China would soon carry Mao's and the Communist movement's story to the world. But the Communist leadership in Yan'an did not introduce her to a single Communist from Shaanbei. Theirs was a new regime of Long March survivors, and "The Kiangsi [Jiangxi] veterans of the Long March were already beings apart from mortal men." 211

Once the War of Resistance broke out, Shaan-Gan-Ning became the Communist rear base, safely removed from the front lines, and Yan'an would be the new center. We have seen the process whereby the borders of the region would be defined in "friction" and armed conflict with the Guomindang, and a local regime would be established, largely from the top down, with critical assistance from the army, especially in Gansu and the northeastern counties occupied by Wang Zhen. To consolidate local control, to build and discipline a local apparatus, it was necessary to turn to local men. By and large, these were not the guerrilla fighters, poor peasants, former bandits, or Society of Brothers leaders who formed the core of Liu Zhidan's Red Army. They were usually men of some education, though typically only at the middle school level, who rose as party organizers or soviet administrators. In the Guanzhong district in the south of the border region, Xi Zhongxun, father of China's current leader, was appointed. From a prosperous family of nearby Fuping, he had joined the party at age fourteen while in middle school in Sanyuan and had considerable experience as an administrator of the local soviet. ${ }^{212}$ In eastern Gansu, Ma Wenrui was the local representative. Ma had joined the party in middle school in Mizhi at age sixteen and been active in the party ever since, often working as a village schoolteacher for cover. In 1938, after brief study in Yan'an, he was sent to Gansu, where he served for seven years. ${ }^{213}$ Liu Zhidan's brother, Liu Jingfan, held ministerial and key secretarial positions in the border region government. ${ }^{214}$ All of these were local men, with some education, and longtime party members who could link the party Center to the local environment. None, however, ever achieved national prominence.

Among the Shaanbei revolutionaries, only Gao Gang rose to membership in the ruling Politburo. An incident from 1940 provides a poignant indication that Gao's status was comparable to that of the Long March survivors. He had just divorced his first wife by an arranged marriage, a local girl whose bound feet were inappropriate for the wife of a rising party leader. He had eyes for a nineteenyear-old normal school student from Jiangsu who had joined the tide of progressive patriots who poured into Yan'an. The party arranged for her to work in his office, then Mao Zedong invited her to dinner with Gao and others, praising Gao's various qualities. She understood the message well enough but had no interest in marriage and feared Gao's fierce temperament. Several days later, another group of party leaders, including Xi Zhongxun, invited her and Gao Gang to a wedding 
banquet. As she recalled the moment years later: "When I heard this, I ran away as fast as I could, ran to the bank of the Yan River. But Wang Ruofei [party elder, then in the central secretariat] found me and said, 'You've studied party-building haven't you? Party members must obey the party. This has been arranged by the party. . . . Just like that, we were married, without any emotion, without a day of love. After we were married, for half a year, Gao Gang wouldn't let me go into town. He was afraid I'd look for my old schoolmates." 215 This was how the party took care of its leaders, and the incident speaks volumes to Mao's regard for this rising son of Shaanbei and the party's treatment of young women as suitable rewards for favored older men.

In 1945, Mao was quite explicit about his thinking-though the gender relations implied by the forced marriage were of no concern to him. Speaking at the Seventh Party Congress, he discussed the importance of paying attention to different groups, which he called "mountain-tops" (shantou 山头), within the party. "When we first came to Shaanbei, we ignored this problem. This border region was built up by Gao Gang and the others by themselves. Because we did not handle this [mountain-top] problem well, some people in Shaanbei started to gossip. Some people said, 'Shaanbei people can only establish a soviet, they can't build a Red Army'. In response, the locals said: 'You marched a long way, but you lost your base, the Jiangxi soviet is no more. We didn't march, but we still have a base in Shaanbei." 216 The gulf separating southern Long March leaders from the Shaanbei revolutionaries could hardly have been clearer. For Mao, the way to bridge this gulf was to cultivate Gao Gang as the representative of the Shaanbei revolution.

Mao stayed in Yan'an until a Nationalist offensive in 1947 drove him from his wartime capital. For the next year, Mao and a small group of leaders hid and marched through the hills of Shaanbei in a much-lauded episode known as "fighting in circles through Shaanbei” (zhuanzhan Shaanbei 转战陕北). Though the enemy was often close on Mao's heels, his location was never revealed. ${ }^{217}$ When he finally crossed the Yellow River a year later, a story popular in the region has him looking back and saying, "Shaanbei is a good place!" There is no evidence that he ever said or even harbored such fond thoughts of the land that had protected him through the long war. After leaving Shaanbei, he would live almost thirty more years, ruling China for most of that period. He never returned to Yan'an. 